\title{
Ways to Improve Effect of College English Translation Teaching
}

\author{
Fang Liu \\ School of foreign languages, Xi'an University, Xi'an, Shaanxi, 710076, China
}

Keywords: College English, Translation teaching, Teaching status, Improvement strategy.

\begin{abstract}
English translation occupies an important position in college English teaching and plays an important role in achieving English teaching objective and enhancing comprehensive English ability. But judging from college English translation teaching, many irrationalities exist, which seriously affect English translation teaching quality and hinder improvement of students' translation ability. The author analyzed the problems existing in college English translation teaching based on the teaching experience for many years, and proposed solutions to these problems, in the hope of promoting college English translation teaching.
\end{abstract}

\section{Introduction}

English as one of universal languages in the world plays a bridge role among the nations and countries of different languages and cultures, and becomes an important medium for various countries in communication and exchange. Under economic globalization, English is used more widely, and English occupies a more important position in our life. This is an important opportunity for college English translation teaching reform and also is a serious challenge to teaching mode and method. In such situation, traditional teaching mode can neither adapt to the development demand in the new era, nor meet students' learning needs. Thus, how to improve the problems in traditional English translation teaching and improve college English translation quality has become a research topic of all colleges.

\section{Importance of college English translation teaching}

For a long time, the main objective of college English teaching in China is to improve students' ability of listening, speaking, reading and writing and train students' oral English communication ability. China has deepened communication with various countries in the world in the continuous development process, so the demand for English translation talents gradually increases. Under the background of economic globalization, English translation gradually turns to a communication mode involving various countries from the past English conversion. Hence, higher requirements are proposed for knowledge reserve and ability of English translators. Understanding cultural customs and human geography of different countries have been the essential knowledge reserve. Such demand for English translation talents provides reform and development opportunities for college English translation teaching. Based on this, college English translation teaching should pay more attention to enriching students' English knowledge reserve, improving translation accuracy, promoting application ability and providing students with employment competitiveness under the condition of guiding students to grasp basic English translation skills. Therefore, to meet social demand for English translation talents, China should attach full importance to English teaching, improve students' translation ability through certain measures and provide high-quality translation talents for the society.

\section{Current situation of college English translation teaching}

At present, English has become an important communication medium in daily study, work and life, and its position in colleges improves increasingly. College English teaching mode is being reformed 
continuously, but some problems occur in the collision of new reform and traditional teaching mode, and seriously affect effect of English translation teaching.

\subsection{Unreasonable setup of English teaching course and textbook}

Currently, English textbooks used by colleges fail to pay sufficient attention to English translation, and textbook setup is mainly manifested as follows: there is short of English-Chinese inter-translation content. Even if there is translation exercise, it just involves translation of original lesson content. Such practice is like things of little value or interest and cannot train translation ability. Seeing from English course setup, the time for English translation is little in English class, and even there is no time left for English translation. Many English teachers get used to assigning English translation as extracurricular work, and just dictate correct translation content in class, without the explanation of translation skills and methods. For example, in "New Horizon" textbooks employed by most colleges, after-class translation exercise usually includes 5-6 sentences. These sentences are relatively simple, and most sentences can be found in the original textbook. If the sentences are not from the original textbook, the syntax and grammar involves are not difficult, and the sentences just involve word exercise learned in the lesson. It can be easily found from such textbook content that, such translation content works little on cultivation of students' translation ability. Such translation content can neither achieve connection between college English translation and the world, nor well connect with the society. It is adverse to students' English translation in work and life.

\subsection{Insufficient attention to English translation course}

Some colleges do not pay sufficient attention to English translation and cannot realize the important status of English translation in employment and social development. Thus, unreasonable course setup time of English translation occurs. Even, there is no English translation course. This seriously affects English translation teaching. In addition, college English teachers cannot realize the important position of English translation in English teaching. They spend lots of energy on cultivation of students' listening, speaking, reading and writing so that students are hard to go deep and lack translation skills in the whole translation process. Since long-term exam-oriented education thought influences students, students learn in order to cope with examinations, and ignore practical application, which hinders English translation teaching. Besides, there is lack of practical ability training.

\subsection{Weak faculty}

The teaching team of College English teaching is weak. Most teachers of English major or translation major teach English major, thus leading to weak English teaching force for non-English major. This is also an important factor influencing translation teaching effect. The whole level of English teaching teams is not high, and teaching level is uneven. These teachers cannot well guide students' translation. The professional level of many teachers is also not high, and they lack understanding of foreign cultural customs and human geography. It is difficult for them to guide students for translation. As colleges gradually increase enrollment, the number of students gradually increases, and the number of teachers is small. Large English class phenomenon exists in many colleges, which is very adverse to students' absorption and practice of English. It is hard for teachers to consider every student in class. All these problems are the factors reducing effect of English translation teaching.

\subsection{Backward teaching mode and unreasonable teaching organization}

Although higher education reform has gone deep continuously, there is still lack of innovation in educational theory. Teachers' teaching methods and ideas also need to innovate and improve. Many teachers still adopt traditional cramming teaching method in English translation teaching. Teacher's explanation is dominated, and students are still in the passive reception state. Such classroom is boring, and lacks interaction. Students naturally lose enthusiasm and initiative. It is very difficult to achieve English translation practice, and students cannot grasp translation skills. Translation teaching 
of college English teachers lacks rational classroom organization, and teaching mode is single and lags behind. These hinder improvement of English translation teaching effect.

\subsection{Ignorance of English application ability training}

Modern English teaching pays more attention to practicability. Thus, college English teachers are required to pay attention to enriching students' knowledge reserve, and regard improvement of practical translation application ability as the fundamental teaching objective. However, many colleges ignore this. Thus, even if students have had certain knowledge reserve, they can neither carry out English translation nor speak English. This deviates from translation talents required by the society.

\section{Strategies to improve effect of college English translation teaching}

\subsection{To pay attention to course reform}

To improve college English translation teaching level is a fundamental way to promote teaching effect. Course reform is an important precondition for changing traditional teaching thought, proposing new teaching ideas and facilitating students' comprehensive English application ability. In college English teaching, it is required to reallocate the period for ability training, and increase the proportion of English translation in English teaching. Except enhancing listening, speaking, reading and writing training, English translation training should be deemed as the key teaching content, and students' translation ability training should be enhanced. It must be mentioned that, teachers should not merely teach students the implication of translation, but should focus on translation skill training and promote translation ability improvement. Apart from enhancing the cognition of importance, textbook content and relevant knowledge should be integrated to improve English teaching practicability.

\subsection{To reform translation teaching method}

As everyone knows, there are multiple solutions to one question. There are also many multiple teaching methods for English translation teaching. When different methods are applied, the emphasis must be different, and the application of one teaching method also has both advantages and disadvantages. How to choose teaching methods in the specific teaching practice? First of all, the selection should be based on teachers' quality, students' comprehensive conditions and the teaching content. There is no fixed teaching method. The key to selection of teaching methods lies in the applicability and teaching result. In addition, translation requires "fidelity, fluency and elegance". In other words, except basic accuracy of translation, translation teaching practicability and artistry should be noticed. For example, many students will literally translate “as timid as a rabbit” into “胆 小的像兔子”. But there is no such sentence in Chinese language code. We often say “胆小如鼠” in Chinese. Therefore, language habits and language art should be noticed in translation process, except accuracy. When we translate Chinese “胆小如鼠” into English, we should not use “mouse”. Thus, teachers should not merely help students translate words accurately, but also pay attention to culture and language habits. In one word, during selection of teaching methods, firstly, it is required to teach basic knowledge and consolidate students' foundation; secondly, teachers should impart translation skills to students, and cultivate students' cultural thinking. In the teaching process, it is required to choose the teaching methods which can mobilize students' enthusiasm and give full play to students' subjective initiative so as to improve their translation level.

\subsection{To improve professional skills of teachers}

Teaching quality is greatly influenced by teachers. Teaching quality plays a crucial role for knowledge imparting and students' acceptance. Teachers' professional quality and teaching skills decide whether students are willing to attend the class and learn actively to certain degree. "There are no poor students but the teachers who cannot teach well”. This speaks volumes for the functions of 
teachers' professional quality and teaching skills in English translation teaching. Improving the quality of teaching staff is an inevitable development tendency of promoting English translation teaching effect. Colleges can provide teachers with the opportunities for exchange with the colleagues in the educational circles through regular skill training, or hold quality and skill competition to improve teachers' quality and level. Meanwhile, both the country and colleges should strongly support college English teachers to improve themselves through learning, further study and other ways, update teaching idea, discover defects in time, actively solve and improve teaching mode. Professional quality improvement and teaching level improvement of college English translation teachers are the important conditions for improving translation teaching effect.

\subsection{To cultivate students' cross-cultural awareness}

English translation refers to conversion of two languages. To reach "fidelity, fluency and elegance" in translation, translators should have certain understanding of historic culture and human geography of both parties. If customs of other parties cannot be grasped, deviations will appear in the translation process. Therefore, Chinese and Western cultural difference is also the basic knowledge that college students should master, which is also the precondition of English translation. Teachers should let students browse historical civilization, cultural customs and geographical conditions about western countries. To acquire such information, except looking up books in the library, western music, films and TV plays are also good choices. Listening to western music and watching films and TV plays can be more easily accepted by students, and such ways can arouse students' interest. Teachers should let students understand western culture and feel the differences of western and Chinese cultural customs through various ways so as to effectively improve students' English translation quality and enhance their comprehensive English ability.

\subsection{To cultivate the ability of translation practice}

English translation has strong practicalness, Compared with other disciplines, English translation pays more attention to students' practical application ability. Thus, English translation teachers should pay moiré attention to English practicalness and apply multiple teaching methods to provide more practice opportunities for students. In practical teaching, teachers can set up rational teaching situations in teaching and train students' translation ability, such as creating business negotiation situation and arranging students for role play. The situational teaching can improve students' participation and learning interest, and promote their translation practice ability. In practice, students can check omissions and defects, and learn from others' strong points to offset one's weakness. At the same time, colleges can provide the internship chance for junior students through cooperation with enterprises to train students' translation ability, promote their application ability and then improve English translation teaching effect.

\section{Summary}

In one word, language is an important tool for mutual exchange and learning. English is an important bridge connecting various countries. Hence, college English teaching should better adapt to social development demand in continuous reform, and regard practice and English application ability training as the teaching objective. Meanwhile, it is required to enhance attention to English translation, improve English translation teaching ability, provide comprehensive talents for the country, promote college English teaching reform and facilitate economic and social development.

\section{References}

[1] Ge Xiaojing, How to improve college English translation teaching effect, English Teacher, 2015, 15(18):89-90+93.

[2] Lv Ning, Study on problems and countermeasures of college English translation teaching, Journal of Hubei University of Science and Technology, 2016,36(03):95-97. 
[3] Luo Ting, Liao Changsheng, Exploration on ways to improve college English translation teaching effect, Comparative Research on Cultural Innovation, 2018,2(14):167+169.

[4] Yin Mingyu, Reform and implementation methods of college English translation teaching mode under network environment, Journal of Beijing Institute of Graphic Communication, 2017,25(06):58-60.

[5] Yu Honghong, On strategies of college English translation teaching innovation based on functional translation theory, Journal of Jilin TV \& Radio University, 2017(02):121-122. 